\title{
MALAYAN WILD LIFE
}

\section{(From the Game Department Report, 1949)}

Wild Life Protection.-The first wild life protection law in Malaya was passed in $\mathbf{1 8 8 4}$ when Strait Settlements Ordinance No. III gave protection to wild birds ; nothing further was done until 1896 when Pahang extended certain protection to Elephant, Seladang, ${ }^{1}$ and Rhinoceros. Other States followed with various measures but conservation was not put on a practical footing until 1921 when the Federated Malay States Wild Animals and Birds Protection Enactment was introduced. From then on a Game Department was in being, though much of the work was performed by honorary game wardens; among them the late Mr. Theodore Hubback.

During the Japanese occupation of Malaya the Game Department disappeared and all departmental records were destroyed. In 1947 the Department re-emerged and measures were taken to adapt its organization to the needs of the Malayan Union.

The matter of wild life preservation is a Federal responsibility. The draft ordinance to revise the existing laws and to make them applicable to the whole of the Federation of Malaya is still unpassed.

Except in the King George V National Park, field work during the present emergency has been almost at a standstill. The Game Wardens and staffs of Headquarters and the States have, in addition to their normal duties, often served as Auxiliary Police, work for which they are particularly well suited. A Special Jungle Squad formed by the Game Warden of Selangor, Negri Sembilan and Malacca, Mr. G. R. Leonard, M.B.E., which included eight Game Rangers, received a special commendation from the Commissioner of Police.

The King George V National Park.--The King George V National Park covers an area of approximately 1,677 square miles of some of the grandest virgin forest country in the States of Pahang, Kelantan, and Trengganu, and was constituted under separate enactments by these three States.

The Dedication of Their Highnesses the Sultans which appears in each State Enactment is as follows :-

"Whereas the Sultans of Pahang, Kelantan, and Trengganu have declared their desire jointly to commemorate the Silver Jubilee of the accession to the Throne of His Majesty King George $\mathrm{V}$ by the dedication of certain lands situate in each

'Seladang (Bibos gaurus) otherwise Gaur or "Indian Bison". 
King George V National Park, Malaya.

Scale 18 miles to 1 inch.

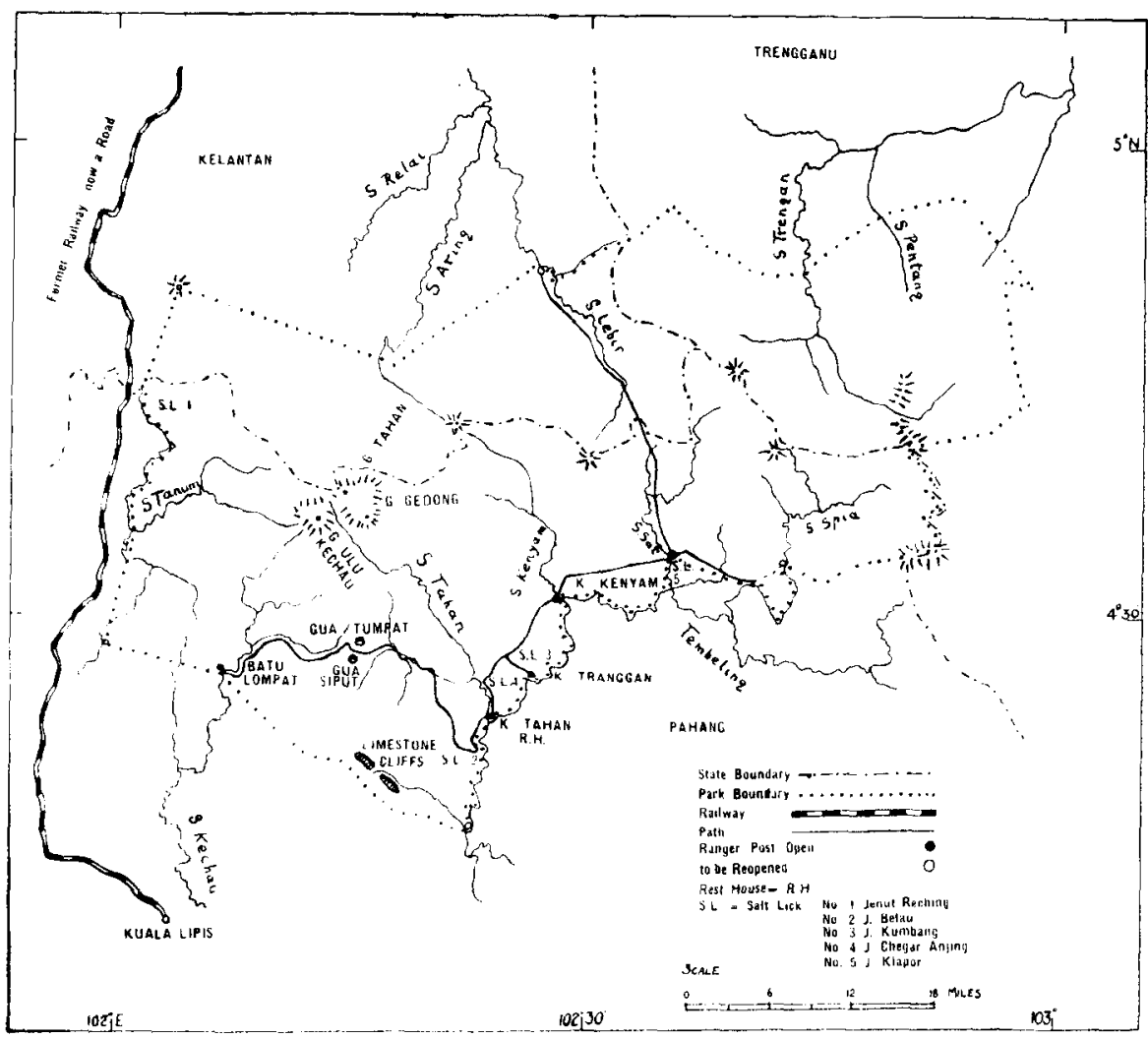


of the said States which shall constitute together a National Park in perpetuity for the protection and preservation of the indigenous fauna and flora of Malaya and which shall be known as The King George V National Park."

Included in the confines of the National Park is Gunong Tahan, whose peak, the highest point in Malaya, rises to 7,186 ft. above sea level.

Ancillary to Gunong Tahan are the following notable mountains, Gunong Ulu Kechau 6,380 ft., Gunong Gedong 6,776 ft., and Gunong Pantat Lesong 5,400 ft.

From the summit of Gunong Tahan, on a clear day, the sea to the north may be seen and also Bukit Jelai on the border of Siam, while to the south Gunong Benom, Frasers Hill, and peaks near to Cameron Highlands are clearly visible.

Numerous rivers drain the Park area, the Tahan, Kenyam, Sat, and Spia flowing into the Tembeling; the Tanum and Kechau into the Jelai ; the Relai, Aring, and Lebir into Kelantan and the Trenggan and Pentang into Trengganu. These rivers with their countless tributaries form a great network of waterways within the Park. Many are navigable in small boats for some miles.

The river Tembeling is the main means of access to the Park and is navigable by outboard motor boat to the Park Headquarters at Kuala Tahan, the journey from Kuala Lipis taking some six hours with good conditions of water.

The National Park is an ideal refuge for almost all species of the fauna and conserves as well the typical flora of the equatorial rain forest. It forms a valuable reservoir for many species of fish and an undisturbed catchment area for rain, discharging as it does, water into three contiguous States.

Administration.-The National Park is vested jointly in the following Trustees : His Excellency The High Commissioner of the Federation of Malaya: Their Highnesses The Sultans of Pahang, Kelantan, and Trengganu. The Trustees appointed the Chief Game Warden, Federation of Malaya, to be Ex-Officio Officer in Charge of the National Park with effect from 29th April, 1948.

Rules for the administration of The National Park were drafted in March and final draft was approved by the Attorney General for submission to the Trustees in June, 1948, the final draft has, however, still not been passed.

Salt Licks.-The following Salt Licks were repeatedly visited and "hides" maintained for observation and photography. 
Jenut Belau.-Seladang and Sambur Deer. Elephant at infrequent intervals.

Jenut Kumbang.-Seladang, Sambur, and Barking Deer. Tiger, Pig, Tapir, and occasionally Elephant and Wild Dog.

Jenut Klapor.-Seladang, Sambur, and Barking Deer. Elephant occasionally.

Artificial Feeding Grounds.-The following were kept up during the year: Chegar Sireh, Chegar Anjing, Chegar Besar, Kuala Tahan, Kuala Trenggan, Kuala Kenyam, and Padang Belar. These feeding grounds are used regularly by both Seladang and Sambur Deer.

At Kuala Tahan there are two small grazing grounds which are frequented almost daily by Sambur. Deer, while Seladang also continue at intervals to enjoy the grazing. From observations made there are without doubt two herds of Seladang which come to these feeding grounds, each with a maximum number of twenty animals, while occasionally odd bulls wander out and show themselves.

When the herds appear they usually stay for several days in the vicinity and have been recorded as staying for as long as fourteen days. They come out of the jungle to graze at all times of the day and are quite undisturbed by the bustle and noise of camp life at Headquarters, which is only a short distance away. The Seladang is, however, by nature a timid animal and does not take unnecessary risks, the taint of human scent in the wind at a distance of approximately eighty yards usually puts the herd to flight, but beyond this distance the herd will ignore human beings going about their lawful occasions.

Electric Fencing.-The erection of electric fencing at Kuala Tahan, which was commenced towards the end of 1948, was completed early in the year and proved successful in keeping Seladang and deer out of the Headquarters compound.

This method of control, which is also effective against elephants, is strongly recommended to rubber and other estates which suffer damage from wild animals. The Game Department is only too willing to give advice on this subject at any time if called upon.

\section{Nature Notes}

Elephants.-Elephants were not observed to any great extent although their fresh spoor may be seen almost everywhere throughout the Park. A family of five were seen twice early in the year near the Ranger's Post at Batu Lompat and a large bull 
wandered into the Ranger's garden at Kuala Tahan from where it was driven with ease after destroying a banana plant.

Elephants frequently visit the many salt licks in the Park, but usually at night, or in the very early hours of the morning, this making observation or photography impossible. The writer does, however, remember an occasion before the last world war when he sat in a hide in the salt lick known as Jenut Kumbang with the late Mr. Theodore Hubback for four days in the hope of securing pictures of elephants. At $4.30 \mathrm{p} . \mathrm{m}$. on the fifth day a small herd of elephants came into the lick and some good pictures were obtained. This however was a stroke of very good luck which may not normally be expected.

The question has often been asked-where do elephants go to die? and suggestions made of a communal burial ground containing fabulous wealth in the matter of ivory if only it could be found!

In Malaya, it is unlikely that the remains of an elephant would be traceable after a period of one year. Very soon after death putrescence occurs and aided by numerous forms of wild life soon destroys the huge carcase, in fact after a period of six weeks there is nothing left but the skull, leg bones, and tusks (if present) and not infrequently these latter have been partially accounted for by porcupines. Within six months the area, which has become highly fertilized, is under a dense floral growth making detection almost impossible. Ultimately the remains become covered with mould and nature preserves one of her secrets.

Seladang.- It is peculiar how the Park herds appear to keep stationary in numbers although not molested in any way through human agency. Each year numerous calves are born and yet on taking a census the herds do not vary more than one or two beasts either way over a period of years. The balance remains very even, losses caused by tigers and old age being replaced by new births.

Early in the year a Seladang was heard bellowing as in pain. This was doubtless a cow in the throes of calf birth for later in the same vicinity a cow was observed with twin calves, a most unusual occurrence for a Seladang.

The following noises made by Seladang were recorded during the year:-

Deep bellowing from a bull, almost a roar ; the high bellowing from a cow in the throes of calf birth; deep mooing; gentle lowing of cow to calf; bleat of a calf; startled snorts and an almost moaning sound. There was no tiger in the area when this moaning sound was heard. 
Sambur Deer.-Sambur Deer are well distributed throughout the Park, particularly near the many tributaries of the Tembeling River. Hardly a day passes when these graceful animals are not observed. On one occasion five Sambur were seen together in Jenut Belau, an unusual occurrence.

Barking Deer.-This small species of deer is not uncommon and may frequently be seen in one or other of the salt licks. A very fine male one day walked across the compound of the Game Warden's house, swam the Tembeling River and wandered about on the opposite bank before taking cover in the jungle.

Tiger.-These animals appear to keep their balance very well. Wherever Seladang, deer and pig are located there also will be found the fresh spoor of Tigers.

Tapir.-Owing to its nocturnal habits and keenly developed senses the Tapir is difficult to observe; they have however been seen near Gua Siput on the path from Batu Lompat to Kuala Tahan and continue to visit Jenut Kumbang. Fresh spoor is always in evidence and it is remarkable the speed at which this seemingly cumbersome animal can gallop over very steep country.

Rhinoceroses.--Old spoor was observed on the hills above and to the east of Gua Siput and there are old wallows along the path from Kuala Tahan to Batu Lompat. This spoor is obviously that of the Two-horned Rhinoceros (Dicerorhinus sumatrensis) and not that of the Javan Rhinoceros (Rhinoceros sondaicus), though this latter species may still be found in the north-cast region of the Park when circumstances permit of an expedition being made into that area.

Wild Dogs.-Tracks of wild dogs were frequently seen in the vicinity of Jenut Kumbang and a pack of five were observed by the Game Warden on the river bank of the Ulu Tahan.

Otters.-Most of the rivers in the Park have their otter families which are quite often surprised by the occupants of a quiet poling boat.

Bears.-There is little evidence of bears in the Park. One was heard to give a sharp bark near Headquarters but this was probably a bear which was released by the Game Warden in the year 1941 .

Apes and Monkeys.-Both Siamang and the White Handed Gibbon are to be found in abundance in the vicinity of Headquarters. The Siamang appears to wander further afield than the latter but comes round at intervals of approximately two weeks. The deep booming call of the Siamang is one of the delights of the forest clad hills. The voice of the White Handed 
Gibbon is a much more plaintive call and daily they serenade the dawn at Kuala Tahan.

The common Brown Monkey (Kera) and Leaf Monkey (Lotong) may be seen in numbers in the vicinity of most rivers and are a pleasure to watch. Those on the river Tembeling have become so accustomed to an outboard motor that they remain seated at the waters edge without alarm while the boat goes roaring by at close quarters.

Game Birds and Others.--The Argus Phcasant and Crested Green Wood Quail are common. The former may be heard daily in numbers but is far too wary to be observed, while the Wood Quail is often flushed on a jungle path. Flights of Imperial Pigeon (Pergam) and Greater Thick-billed Green Pigcon (Berkok) may frequently be seen, also four different species of Hornbills with their peculiar intermittent flight.

The many species of birds to be found in the Park are far too numerous to list but are fully representative of Malayan Avifauna. It is interesting to note that the Tree Sparrow has not yet been recorded in the Park and that for the first time the Yellow Vented Bulbul and Spotted Dove were observed during the year.

Note.-Since going to Press a letter has been received from Mr. A. H. Fetherstonhaugh, Chief Game Warden, Federation of Malaya, that the situation at the end of 1950 in the King George V National Park was substantially the same as in the above report. Some progress in rehabilitation and field observation was made.-ED.

\section{UGANDA}

\section{(From the 1949 Report of the Game Department)}

\section{Game Reserves and Sanctuaries}

Bunyoro and Gulu.-On the whole this reserve continues to be well stocked particularly in the vicinity of the River Nile. That parts of it are still poached is unquestionable, but it is a moot point whether a conspicuous, local shortage of kob and hartebeest is due to poaching or to the depredations of lions. Baboons in the Murchison Falls Nile region have shown an astonishing increase in recent years which is almost certainly attributable to the widespread harrying to which the skin-valuable leopard has been subjected. Hippopotamus poaching in the Nile has by no means ceased, and the remote control which is only possible 